\title{
Risk and Uncertainty in Sustainable Development: Undertaking Politics of the Climate Change in the United States
}

\section{Ryzyko i niepewność w zakresie zrównoważonego rozwoju: kwestia polityki wobec zmian klimatu w Stanach Zjednoczonych}

\section{Olena Ovchynnikova}

\author{
United Nations System Staff College Knowledge Centre for Sustainable Development, \\ Knowledge Centre for Sustainable Development, \\ United Nations System Staff College, Martin-Luther-King-Straße 8, \\ Bonn 53175, Germany \\ E-mail: o.ovchynnikova@unssc.org
}

\begin{abstract}
Scientific evidence of climate change has never been more profound. Activists around the world now demand climate action from global leaders on almost a daily basis. Yet, decision makers are not in a rush to deal with the climate emergency. The present article looks at the politics of climate change through the lens of decision-making under uncertainty to understand whether uncertainty and risk can explain the lack of decisive action on the part of the global leadership and posits that the politics of climate change reflect the climate system itself: complex, multi-layered, driven by many inter-related elements and diverse in its manifestations.
\end{abstract}

Key words: climate change, risk, uncertainty, climate change politics, sustainable development, urban development

\section{Streszczenie}

Naukowe dowody odnoszące się do zmian klimatu są niepodważalne. Aktywiści na całym świecie wymagają od globalnych liderów działań klimatycznych niemal codziennie. Jednak decydenci nie spieszą się z rozwiązaniem kryzysu klimatycznego. W niniejszym artykule przyglądamy się polityce zmian klimatu przez pryzmat podejmowania decyzji w warunkach niepewności, aby zrozumieć, czy niepewność i ryzyko mogą wyjaśnić brak zdecydowanych działań ze strony światowego przywództwa i zakładamy, że polityka zmian klimatu odzwierciedla system klimatyczny sam w sobie: złożony, wielowarstwowy, napędzany przez wiele powiązanych ze sobą elementów i różnorodny w swoich przejawach.

Słowa kluczowe: zmiany klimatyczne, ryzyko, niepewność, polityka odnośnie zmian klimatu, rozwój zrównoważony, rozwój miast

\section{Introduction}

In 1998, one of the world's largest oil companies ExxonMobil embarked on a strategy to manufacture uncertainty regarding climate change (Shulman, 2007). The objective was to oppose policies to limit the use of fossil fuels and discredit them as such that lack public support. If introduced and implemented successfully such policies might have had serious consequences for ExxonMobil (Patt and Weber, 2014). Indeed, without public acceptance and support, policy development and implementation are inevitably problematic (Lorenzoni and Pidgeon, 2006). 
Since that time, climate change research community has gone far in terms of consensus and evidence about climate change (Stern, 2006; Stern, 2015; Schmidt, 2015) and has significantly improved communication on uncertainty, starting from Intergovernmental Panel on Climate Change (IPCC) guidance notes (Moss and Schneider, 2000; Manning et al., 2004; Mastrandrea et al., 2010) to academic research of climate policy communication strategies (Tol, 2003; Moser, 2010). Alongside these scientific developments, there have been some important shifts at the policy level: a $2^{\circ} \mathrm{C}$ target was accepted together with emission reduction targets; national climate change plans and voluntary commitments were adopted, etc. (Hasselmann and Barker, 2008; Barker, 2008). It is, however, difficult to attribute these achievements of climate change politics to the increase of certainty about climate hazards and their anthropogenic nature. Moreover, these shifts in the politics of climate change are interesting, as numerous surveys across the globe indicate a growing scepticism among decision makers with regard to climate change (Lieserowitz, 2006). Recent surveys in the US, European Union, Australia, Canada, and New Zealand demonstrate a decline in the level of recognition of climate change and its man-made nature (Ratter et al., 2012). This is particularly interesting in the case of the United States, where the federal level of government remains resistant to taking decisive action on this political issue despite growing evidence and numerous climate related natural disasters that hit the United States in the recent years. At the same time, the level of action at the local level has grown tremendously with the greenhouse gas emissions in the US have remained at almost the same level since 1990 (US Environment Protection Agency, 2019).

What does this tell us about the relationship between uncertainties and the politics of climate change in the US? Have the American decision makers simply become accustomed to the perceptions of climate change risks and uncertainties? Have they been convinced by the growing evidence, data and scientific consensus? Are uncertainties and risks, and their perceptions by the decision makers and general public, central to understanding politics of climate change? Academic literature offers a variety of answers to the questions about uncertainty and risk and how they impact decision making. Webster et al. claim that formulation of climate change policy automatically poses a great challenge because it presents a problem of decision-making under uncertainty (2003, p. 295). Patt and Weber indicate that climate policy itself may be becoming less and less sensitive to the existence and perception of climate uncertainty, and at the same time more and more sensitive to uncertainty in other systems, social systems in particular (2013, p. 220). Charlesworth and Okereke (2010) go further to argue often uncertainty has been conveniently used as an excuse for inaction.

The present article shares these diverse and somewhat conflicting positions and puts forward the following hypothesis: very much like the climate system itself - a complex interactive system with many feedback effects (Prins and Rayner, 2009) - the politics of climate change are driven by a myriad of sometimes interconnected and sometimes independent causes and factors, including but not limited to uncertainty and risk. Economic opportunities, environmental benefits, political interests, socio-cultural factors, competitive pressure, lack of immediate personal experience, and many other factors are important to understand a full picture of the climate change politics.

The argument will start with definitions of key concepts that will be used throughout the text: politics of climate change, uncertainty, and risk. The next section will examine the politics of climate change in the United States of America, one of the world's largest emitters of carbon dioxide. The US are chosen for this study for a number of reasons. First of all, the country is one of the biggest emitters of greenhouse gases globally. Second, the US has been hit particularly hard by the latest natural disasters with most of them attributable to climate change as the main cause. Third, unlike other countries, public push for climate action in the US has not been particularly strong. According to Kamarck (2019), in 2015 , after an unusually cold and frigid winter, only $37 \%$ of Americans were concerned with the risks of climate change. In 2019, following Hurricanes Harvey and Irma in 2017, California wildfires and record high heat waves of summer 2019, this number grew only to $42 \%$ of the public. However, despite all of this, the local level politics of climate action is going in the positive direction with many American cities and states taking initiatives and voluntary commitments to curb emissions and move to a cleaner future. Having analysed the US climate change politics, the concluding part will then bring together the small pieces of the patchwork to revisit the hypothesis to confirm or dismiss it.

\section{Key Concepts: Politics of Climate Change, Risks and Uncertainties}

Anthony Giddens (2009, p. 4) maintains that we have no politics of climate change. What Giddens implies is the absence of coherent and coordinated nationwide politics (and geopolitics) aimed to respond to climate change. The present article embraces a wider definition of politics, whereby decisions regarding climate change response are made not only by national governments or international bodies but also by regional and municipal governments, nongovernmental actors, private sector, interest groups, etc. 
Although climate change is often regarded as a global problem that requires a top-down solution, many initiatives beyond the international and national levels have proven that bottom-up politics are important to drive national and international decision making.

For example, cities account for up to $75 \%$ of global greenhouse gas (GHG) emissions (Stern, 2006). The initiatives such as the Cities for Climate Protection, Climate Alliance, and C40 Cities Climate Leadership Group bring together hundreds of cities across the globe. Their political stance can sometimes oppose national governments (as is the case of the US) and lead to the adoption of international agreements (e.g. Bali World Mayors and Local Governments Climate Protection Agreement adopted at the 2007 Conference of the Parties to the UN Framework Convention on Climate Change) (Bulkeley, 2010). These initiatives are of utmost importance for understanding the politics of climate change and its key parameters and drivers. This article thus recognizes both top-down and bottom-up politics of climate change and will draw on examples and case studies of the various levels of politics.

Despite the growing scientific evidence and consensus on climate change, uncertainty still abounds in climate change and the politics of responding to it (Tol, 2003). The IPCC Working Group III in their Contribution to the Fifth Assessment Report (AR5) defines uncertainty as a cognitive state of incomplete knowledge that results from a lack of information and/or from disagreement about what is known or even knowable (Kunreuther et al., 2014, p. 155). Scholars differentiate between different types of uncertainties (Hammitt; 1995; Shimmelpfennig, 1996; Kann and Weyant, 1999; Patt and Weber, 2014). In broad terms, literature on uncertainties can be roughly divided into two broad streams: uncertainties about climate change as a phenomenon (and tools and theories applied to analyse this uncertainty for decision-making) and other uncertainties (uncertainties regarding technologies; uncertainties associated with market behaviour; uncertainties about human preferences, etc.). IPCC AR5 adopts the approach suggested by Patt and Weber (2014) that the following uncertainties affect policy choices:

- Uncertainties regarding GHG emissions, and their associated impacts;

- Uncertainties about stocks and flows of carbon and other GHGs;

- Uncertainties regarding technological systems;

- Uncertainties regarding market behaviour and regulatory actions;

- Uncertainties based on individual perceptions (Kunreuther et al., 2014, p. 158).

The AR5 then goes further to build taxonomy of levels of decision making (international, national, local or regional, industry or firm, and individual) and cli- mate change policies with relation to the above mentioned uncertainties. This article embraces this taxonomy presented in AR5 to review the hypothesis. Climate change has potential adverse effects for people, ecosystems, infrastructure, social systems, etc. Uncertainties about the impacts of climate change, technological systems, market behaviour and others amplify these risks for decision makers (Barnett, 2001). Not always are risks known and certain; sometimes they may be subjective or perceived only. Risks, as Harvey claims (1996a), justify actions. Thus, the very choice of climate policies is seen as risk management exercise (Kunreuther et al., 2013, p. 1), the purpose of which is to identify uncertainties and risks, evaluate strategies, and identify and design a robust policy. As, Pizer insists, analyses which ignore uncertainty can lead to inefficient policy recommendations (2013, p. 1). Researchers use various theories, frameworks and tools to enable decision makers examine a range of possible outcomes: expected utility theory, cost-benefit analysis, cost-effectiveness analysis, adaptive management, etc. (Kunreuther et al., 2014). On the other hand, Rayner notes that quest for certainty and accurate cost-benefit analysis simply serve as justifications for lack of decisions and action (cited in Charlesworth and Okereke, 2010). Risk and uncertainty management strategies rely on the premise that decision-makers, interest groups, and beneficiaries use rational choice models to arrive at a calculated decision (Lieserowitz, 2006), while the analysis of decisions made and actions taken by various stakeholders of climate change politics reveal the use of intuitive thinking and reliance on value judgements alongside deliberative thinking.

Using the IPCC taxonomy of levels of decision making and climate policy choices regarding key uncertainties that matter for climate change politics, the following section will review decisions and actions exercised by those in power at the national, regional, subnational or local scales in the United States with the objective to how see if uncertainties and risks are central to understanding the results achieved or not achieved in the area of climate change politics or whether other considerations should be factored in.

\section{Uncertainties and Risks in the Politics of Climate Change in the United States}

In 2001, the US President G.W. Bush announced the withdrawal of the United States from the Kyoto Protocol - an international agreement linked to the United Nations Framework Convention on Climate Change, which commits its Parties by setting internationally binding emission reduction targets - stating that the Kyoto Protocol would cause harm to the US economy (Bush quoted in Nordhaus, 2007, p. 686). This decision was presumably based on the 
economic analysis, which suggested that the Kyoto Protocol was costly. However, that analysis - published a year after the withdrawal from the Kyoto Protocol - did not show that the commitment would be economically unjustifiable and active denial of the scale and risks presented by climate change was not driven by a response to the high degree of uncertainty regarding causes and responses to climate change (Nordhaus, 2007). In similar situations of high uncertainty and lack of pristine predictions, decisions were taken to engage in action and make relevant commitments: the US participation in the Montreal Protocol, under which uncertainties regarding plausible ozone depletion - and emissions of carbofluorocarbons (CFCs) that cause it - were as great as uncertainties regarding climate change when the decisions were made (Hammitt, 1995). The difference in responses to these global climate threats is accounted for by the difference of the importance of CFCs and fossil fuels for the US economic and political interests. In a very simplistic level of explanation, the rejection of the politics of climate change in the US at the federal level was guided by the vested interests in the consumption of fossil fuels, which results in GHG emissions but which are the basis of the US economy and not uncertainties and risks of climate change events (Demeritt, 2006).

Despite the lack of coherent and systematic policies at the federal level, a number of US states, local and municipal governments are taking action to voluntarily cut emissions by a different level (Powledge, 2012). Wheeler's analysis of climate change plans of 29 US states and cities with populations of over 500,000 reveal that most of them undertake emissions inventories, set emissions reduction targets, and offer action plans as climate change action [is] a moral imperative (2008, p. 484). Underlying factors for development and implementation of these plans are as diverse as the states themselves: economic opportunities (savings and potential investments), environmental benefits (clean air, pollution control), political self-interest (politicians claiming credit for climate change actions) (Betsill, 2001; Rabe, 2008), conducive legal environment (1990 State and Local Climate Change; 1992 Energy PolicyAct and 1990 Clean Air Act Amendments, etc.) that provided incentives for beginning a process of policy development) (Rabe, 2007) and others. On the other side of the spectrum are the states (e.g. Wyoming, West Virginia, Pennsylvania, North Dakota, Colorado, Alabama) that passed resolutions to block action on GHG emissions reduction and press the federal government to reject the Kyoto Protocol, (Hassol and Udall, 2003). Ironically, these states have experienced some of the most adverse weather events attributed to climate change. They also face about the same level of risks and uncertainties as those that have adopted climate change plans. The difference is that this group of states include the largest coal producers in the US, whose economic interest outweigh values of public health and safety, public support for actions against climate change, and other considerations, as well as may be even the logic of economic analysis which presents opportunities of savings and greater economic benefits in the long-term perspective. (Hassol and Udall, 2003). In a nutshell, at the state and regional level in the US, action and inaction with regard to climate change is guided by a myriad of factors and identification of risks and uncertainties regarding the emissions impact and climate responses are not enough to understand the politics of climate change at this level.

At the next level of decision-making - that of industry and firms- a similar situation is observed. In addition to the uncertainties regarding climate sensitivity and thresholds, companies face other uncertainties and risks, such as uncertainties concerning technologies and technological system and relevant risks to invest in technology research and development; regulatory risks and uncertainties, etc. In fact, unlike their European and other counterparts, US companies have to operate in an even cloudier environment, after the withdrawal from the Kyoto Protocol, as the regulatory space became even more uncertain (Hoffman, 2005). It is so more surprising that a growing number of corporations and enterprises have adopted voluntary commitments to reduce emissions and factored in climate change into their strategies. There are several drivers that account for this progress. First, climate change is increasingly regarded as a business opportunity:

Companies at the vanguard no longer question how much it will cost to reduce greenhouse gas emissions, but how much money they can make doing it (Cogan cited in Jones and Levy, 2007).

However, beyond the level of potential economic benefit that is a key driver for any enterprise, business responses to climate change can be viewed through different lenses. These lenses differ among industries. For agriculture, tourism, insurance, and some other industries, climate change presents a physical threat (change in yields; shortening of tourist seasons; change in insured losses, etc.). The automobile industry is motivated by competitive pressures: for instance, Ford, Daimler-Chrysler, and General Motors were forced by the competitors to consider developing fuel saving cars (Hassol and Udall, 2003). Utility companies are driven by the uncertainties in the future carbon regulations. Analysis of 15 electric utilities in the Western United States by Barbose et al. (2008) reveals that it is not only the regulatory risk but also the likelihood of the introduction of these regulations that influence the decision-making and responses of the utilities. These risks and uncertainties are then coupled with investment and other risks. Reponses to multiple risks and 
uncertainties have also changed overtime: from opposition and challenge of the science of climate change (as was the case with the ExxonMobil manufacturing uncertainty campaign) to adopting voluntary emissions reduction targets. Although it is difficult to make generalizations about diverse industries, it is safe to say that uncertainties and risks as drivers for decisions regarding climate change politics loom large in the corporate world, alongside traditional economic benefit considerations.

Finally, at the individual level, a number of additional factors have an impact on public perceptions and their support for climate change policies. Cultural values, personal experiences and beliefs, and intuitive thinking models are more pronounced. This is not to say that these factors do not make their way to the politics at the state, local or enterprise level, but are more easily detectable at the individual level. By 2006, surveys of the US public indicated that Americans are aware of climate change $(92 \%)$ and think that its reality is proven by scientific consensus (61\%) (Lieserowitz, 2006). However, surveys undertaken in 2009-2010 show a decline both in belief in scientific evidence on climate change (-14\%) and the level of perception of climate change as a serious problem (-10\%) (Ratter et al., 2012). This is often explained by the growing importance of other threats and risks (terrorism, financial crisis, etc.) and a lack of personal experience with climate change. However, whenever people have direct experience of adverse weather events (such as floods, for instance) decisions that they make are not always based on the experience of the event as such (as in cases when Americans after the floods considered the risk and likelihood low and did not buy insurance even when it was highly subsidized) (Patt and Schroter, 2008). Overall, research shows that public risk perception and preferences are influenced by socio-political factors (Lieserowitz, 2006), cultural and value judgements, and are mostly explained by intuitive decision-making, focus on short-term perspectives, loss aversion, etc. (Kunreuther et al., 2014).

\section{Discussion and Conclusion}

The article tried to prove that although identifying risk and uncertainty are important to understand the politics of climate, there is a myriad of other interconnected and independent causes and factors that influence the thinking and decisions of the politicians and stakeholders at various levels of decisionmaking. Because the climate system is a complex system, there still are (and for some time will be) multiple uncertainties that limit our knowledge of the impact of the GHG emissions on people, ecosystems and other systems, safe and dangerous thresholds, and feedback systems, decision-making will need to take place against this canvas of uncertainties, ambiguities, and risks. This has led to the claim that risk and uncertainty are central to understanding politics of climate change. However, a quick review of the decisions and actions taken at the federal, state, company, and individual levels in the United States reveals that risk and uncertainty play a central role for some decisions and actions but are also often used as excuses for inaction (Charlesworth and Okereke, 2010). Literature analysis on the US climate politics demonstrate that a growing number of decisions and commitments cannot be explained within the framework of risk and uncertainty only. Economic opportunities, environmental benefits, political interests, socio-cultural factors, competitive pressure, lack of immediate personal experience and many other factors are important to understand a canvas of the climate change politics.

The present review only looked at the decision made and commitments taken, but have not analysed their level of implementation, which is, as recognized by researchers and experts, low at all levels. In addition to the reasons and factors that are either stated or easy to identify, there are other reasons that have an impact on the final outcome of the politics of climate change: institutional capacities, issues of trust, leadership, accountability and jurisdiction, and others, which could not have been explored within this short article to have a full and comprehensive picture of the climate change politics. What can be said without reservation is that the politics of climate change reflect the climate system itself: complex, multi-layered, driven by many inter-related elements and diverse in its manifestations.

\section{References}

1. BARBOSE G., WISER R., PHADKE A., GOLDMAN CH., 2008, Managing carbon regulatory risk in utility resource planning: Current practices in the Western United States, in: Energy Policy, 36(9), p. 3300-3311.

2. BARKER T., 2008, The economics of avoiding dangerous climate change. An editorial essay on the Stern review, in: Climate Change, 89, p.173-194.

3. BARNETT J., 2001, Adapting to Climate Change in Pacific Island Countries: The Problem of Uncertainty, in: World Development, 29(6), p. 977-993.

4. BETSILL M. M., 2001, Mitigating Climate Change in US Cities: Opportunities and obstacles, in: Local Environment, 6(4), p. 393-406.

5. BULKELEY H., 2010, Cities and the Governing of Climate Change, in: Annual Review of Environment and Resources, 35, p. 229-253.

6. CHARLESWORTH M., OKEREKE CH., 2010, Policy responses to rapid climate change: An epistemological critique of dominant approaches, in: Global Environmental Change, 20(1), p. 121-129.

7. DEMERITT, D., 2006. Science studies, climate change and the prospects for constructivist critique, in: Economy and Society, 35(3), p. 453-479.

8. GIDDENS A., 2009. The Politics of Climate Change, Polity, Cambridge. 
9. HAMMITT J., 1995, Outcome and value uncertainties in global-change policy, in: Climatic Change, 30(2), p. 125-145.

10. HARVEY L.D.D., 1996a, Development of a riskhedging $\mathrm{CO}_{2}$-emission policy, part I: Risks of Unrestrained Emissions, in: Climatic Change, 34(1), p.140 .

11. HARVEY L.D.D., 1996b, Development of a riskhedging $\mathrm{CO}_{2}$-emission policy, part II: Risks associated with measures to limit emissions, synthesis, and conclusions, in: Climatic Change, 34(1), p.41-71.

12. HASSELMANN K., BARKER T., 2008, The Stern review and the IPCC fourth assessment report: implications for interactions between policymakers and climate experts. an editorial essay, in: Climate Change, 89, p. 219-229.

13. HASSOL S.J, UDALL R., 2003, A Change of Climate, in: Issues in Science and Technology,19(3), p. 1-10.

14. HOFFMAN A.J., 2005, Climate Change Strategy: The Business Logic Behind Voluntary Greenhouse Gas Reductions, California Management Review, 47(3), p. 21-46.

15. JONES Ch. A., LEVY D.L., 2007, North American Business Strategies Towards Climate Change, in: European Management Journal, 25(6), p. 428440

16. KANN A., WEYANT J., 2000, Approaches for performing uncertainty analysis in large-scale energy/ economic policy models, in: Environmental Modeling \& Assessment, 5(1), p. 29-46

17. KAMARCK E., 2019, The challenging politics of climate change, Brookings Report (23 September), https://www.brookings.edu/research/the-challenging -politics-of-climate-change (25.10.2019).

18. KENNEDY B, HEFFERON M., 2019, U.S. concern about climate change is rising, but mainly among Democrats, Pew Research Center, August 28, https:// www.pewresearch.org/fact-tank/2019/08/28/u-sconcern-about-climate-change-is-rising-but-mainlyamong-democrats/ (21.10.2019).

19. KUNREUTHER H., GUPTA S., BOSETTI V., COOKE R., DUTT V., HA-DUONG M., HELD H., LLANES-REGUEIRO J., PATT A., SHITTU E., WEBER E., 2014, Integrated Risk and Uncertainty Assessment of Climate Change Response Policie, in: Climate Change 2014: Mitigation of Climate Change. Contribution of Working Group III to the Fifth Assessment Report of the Intergovernmental Panel on Climate Change, eds. Edenhofer, O., R. Pichs-Madruga, Y. Sokona, E. Farahani, S. Kadner, K. Seyboth, A. Adler, I. Baum, S. Brunner, P. Eickemeier, B. Kriemann, J. Savolainen, S. Schlömer, C. von Stechow, T. Zwickel and J.C. Minx, Cambridge University Press, Cambridge, United Kingdom and New York, NY, USA.

20. KUNREUTHER H., HEAL G., ALLEN M., EEDENHOFER O., FIELD C.B., YOHE G., 2013, Risk management and climate change, in: Published Articles \& Papers, paper 172, http://research.create.usc.edu/cgi/viewcontent.cgi $?$ article $=1173 \&$ context=published_papers> (25.10.2019).

21. LEISEROWITZ A., 2006, Climate Change Risk Perception and Policy Preferences: The Role of Affect,
Imagery, and Values, in: Climatic Change, 77(1), p. 45-72.

22. LORENZONI I., PIDGEON N. F., 2006, Public Views on Climate Change: European and USA Perspectives, in: Climatic Change, 77(1), p.73-95.

23. MANNING M., PETIT M., EASTERLIN D., MURPHY J., PATWARDHAN A, ROGNER H-H., SWART R., YOHE G., 2004, Workshop Report: IPCC Workshop on Describing Scientific Uncertainties in Climate Change to Support Analysis of Risk and of Options, Intergovernmental Panel on Climate Change, https://www.ipcc.ch/pdf/supporting-materi al/ipcc-workshop-2004-may.pdf (5.09.2019).

24. MASTRANDREA M.D., FIELD C.B., STOCKER T.F., EDENHOFER O., EBI K.L., FRAME D.J., HELD H., KRIEGLER E., MACH K.J., MATSCHOSS P.R., PLATTNER G.-K., YOHE G.W., ZWIERS F.W., 2010, Guidance Note for Lead Authors of the IPCC Fifth Assessment Report on Consistent Treatment of Uncertainties. Intergovernmental Panel on Climate Change (IPCC), https:// www.ipcc.ch/pdf/supporting-material/uncertaintyguidance-note.pdf (24.09.2019).

25. MOSER S., 2010, Communicating climate change: history, challenges, process and future directions, in: Wiley Interdisciplinary Reviews: Climate Change, 1(1), p.31-53.

26. MOSS R.H., SCHNEIDER S.H., 2000, Uncertainties in the IPCC TAR: Recommendations to lead authors for more consistent assessment and reporting, in: Guidance Papers on the Cross Cutting Issues of the Third Assessment Report of the IPCC, eds. Pachauri R., Taniguchi T. and Tanaka K., World Meteorological Organization, Geneva, p. 33-51, http://citeseerx.ist.psu.edu/viewdoc/download?doi=10.1.1.399.6 290\&rep=rep1\&type $=$ pdf $(25.10 .2019)$.

27. NORDHAUS W.D., 2007, A Review of the 'Stern Review on the Economics of Climate Change', in: Journal of Economic Literature, 45(3), p. 686-702.

28. PATT, A., SCHRÖTER D., 2008, Perceptions of climate risk in Mozambique: Implications for the success of adaptation strategies, in: Global Environmental Change, 18(3), p.458-467.

29. PATT A., WEBER E. U., 2014, Perceptions and Communication Strategies for the Many Uncertainties Relevant for Climate Policy, in: WIREs Climate Change, 5, p. 219-232.

30. PIZER W. A., 1999, The optimal choice of climate change policy in the presence of uncertainty, Resource and Energy Economics, 21, p. 255-287.

31. POWLEDGE F., 2012, Scientists, Policymakers, and a Climate of Uncertainty. Can research gain a foothold in the politics of climate change?, in: BioScience, 62(1), p.8-13.

32. PRINS G., RAYNER S., 2009, How to Get Climate Policy Back on Course, Institute for Science, Innovation and Society, LSE.

33. RABE B. G., 2007, Beyond Kyoto: Climate Change Policy in Multilevel Governance Systems, in: Governance: An International Journal of Policy, Administration, and Institutions, 20(3), p. 423-444.

34. RABE B. G., 2008, States on Steroids: The Intergovernmental Odyssey of American Climate Policy, Review of Policy Research, 25(2), p. 105-128. 
35. RATTER B.M.W., PHILIPP K.H.I., von STORCH H., 2012, Between hype and decline: recent trends in public perception of climate change, in: Environmental Science and Policy, 18, p. 3-8.

36. SAAD L., 2015, U.S. Views on Climate Change Stable After Extreme Winter, Gallup, March 25, https://news.gallup.com/poll/182150/views-climatechange-stable-extreme-winter.aspx (22.10.2019).

37. SCHIMMELPFENNING D., 1996, Uncertainty in Economic Models of Climate-Change Impacts, in: Climatic Change, 33, p. 213-234.

38. SCHMIDT L. J., 2015, Twelve years of satellite data help decode climate change, in: NASA Features, http://climate.nasa.gov/news/2264/ (24.10.2019).

39. SHULMAN S., 2007, Smoke, Mirrors and Hot Air: How ExxonMobil Uses Big Tobacco's Tactics to Manufacture Uncertainty on Climate Science, Union of Concerned Scientists, Cambridge, MA, http:// www.ucsusa.org/sites/default/files/legacy/assets/doc uments/global_warming/exxon_report.pdf (21.10.2019).

40. SMITH A.B., 2018, 2017 U.S. billion-dollar weather and climate disasters: a historic year in context, https://www.climate.gov/news-features/blogs/beyon d-data/2017-us-billion-dollar-weather-and-climatedisasters-historic-year\#targetText=During\%202017 $\% 2 \mathrm{C} \% 20$ the $\% 20$ U.S.\%20xperienced,crop\%20free ze $\% 2 \mathrm{C} \% 20$ drought $\% 20$ and $\% 20$ wildfire (25.10.2019).
41. STERN N., 2006, Stern Review on the Economics of Climate Change, HM Treasury/Cabinet Office, London, http://webarchive.nationalarchives.gov.uk/201 00407011151/http://www.hm-treasury.gov.uk/stern _review_report.htm (20.12.2018).

42. STERN N., 2015, Why Are We Waiting? The Logic, Urgency, and Promise of Tackling Climate Change, MIT Press.

43. TOL R., 2003, Is the uncertainty about climate change too large for expected cost-benefit analysis?, in: Climatic Change, 56, p. 265-289.

44. US Environment Protection Agency, 2019, Inventory of U.S. Greenhouse Gas Emissions and Sinks: 19902017, https://www.epa.gov/ghgemissions/inventoryus-greenhouse-gas-emissions-and-sinks (25.10.2019).

45. WEBER E.U., 2011, Psychology: Climate Change Hits Home, in: Nature Climate Change, 1(1), p. 2526.

46. WENSTER M., FOREST Ch., REILLY J., BABIKER M., KICKLIGHTER D., MAYER M., PRINN R., SAROFIM M., SOKOLOV A., STONE P., WANG CH., 2003, Uncertainty Analysis of Climate Change and Policy Response, in: Climatic Change, 61(3), p. 295-320.

47. WHEELER S., 2008, State and Municipal Climate Change Plans: The First Generation, in: Journal of the American Planning Association, 74(4), p. 481496. 
